The University of Southern Mississippi The Aquila Digital Community

Faculty Publications

$12-1-1993$

\title{
Tennessee Williams \& Elia Kazan: A Collaboration in the Theatre
}

Philip C. Kolin

University of Southern Mississippi, philip.kolin@usm.edu

Follow this and additional works at: http://aquila.usm.edu/fac_pubs

Part of the English Language and Literature Commons

\section{Recommended Citation}

Kolin, P. C. (1993). Tennessee Williams \& Elia Kazan: A Collaboration in the Theatre. Theatre Journal, 45(4), 565-566.

Available at: http://aquila.usm.edu/fac_pubs/6707

This Book Review is brought to you for free and open access by The Aquila Digital Community. It has been accepted for inclusion in Faculty

Publications by an authorized administrator of The Aquila Digital Community. For more information, please contact Joshua.Cromwell@usm.edu. 
work of Erika Mann. Her short lyric "Mrs. X" is an exquisite gem which shows that the "epic" music-theatre style was by no means Brecht's alone. Moreover, "Mrs. X" summarizes the plight of a German woman shopkeeper in the 1930s from a gendered viewpoint which Brecht could never approximate. Senelick closes the whole period in dramatic fashion by including Joseph Goebbels's 1941 "Order Prohibiting Masters of Ceremonies and Commentary from the Stage," the cabaret theatre's own special entry permit into the regions of $e n-$ tartete kunst ("degenerate art").

Throughout the book Senelick builds nuanced distinctions among the many different styles of the form: music hall, revue, cabaret, mittelstück, and cabaret artistique. In addition, he gives us a focused look at particular features of the form, such as the developing role of conferencier, who, we can now see, was the forerunner of the solo performance monologuist of the 1980s and 1990s. Senelick has also done a remarkable job translating, into theatrically proficient English, texts based on local political and cultural issues and laced with local slang.

Some of the shortcomings in Cabaret Performance Volume II have to do with the immensity and unfamiliarity of the genre Senelick helps uncover. Most of the material here will be utterly new to American readers, and yet there is no index to help the reader organize and correlate unfamiliar names and titles. There is also no bibliography and, worse, not even a listing of sources for the texts which do appear. Senelick's book is also sparse on information about stage design, performance style, and the physical nature of cabaret venues - what were they like to perform in, what was it like to watch the performances?

Perhaps Senelick considers such explanations the work of other studies to come. (Harold Segel's Turn-of-the-Century Cabaret does provide this type of information for the era covered in Senelick's first volume). It is hard to imagine how such studies won't follow the fascinating and absorbing groundwork laid out by Cabaret Performance Volume II.

JOHN BELL Long Island University
TENNESSEE WILLIAMS \& ELIA KAZAN: A COLLABORATION IN THE THEATRE. By Brenda Murphy. New York: Cambridge University Press, 1992; pp. 201. $\$ 37.95$.

Brenda Murphy's book is a major study, required reading in fact, of the composition and production of the four major plays (Streetcar, Camino Real, Cat on a Hot Tin Roof, and Sweet Bird of Youth) and two lesser works (Rose Tattoo and Baby Doll) on which Kazan collaborated with Williams from 1947 until 1960. As Murphy persuasively argues, "Despite its eventually destructive dynamic, the Williams-Kazan relationship was central to some of the best work that either man did" (7). Through a scrupulous examination of the script/text versions of the plays, interviews, autobiographies, letters, and notebooks, Murphy demonstrates how pervasive yet challenging the director's control was over Williams. Together both men, with the help of designer Jo Mielziner, created the "American Style" in the 1950s.

Murphy contends that Kazan was the "perfect collaborator" for Williams who, in a key letter to the director, pinpointed why he needed Kazan's magic - "The cloudy dream type, which I admit to being, needs the complimentary eye of the more objective and dynamic worker. I believe you are also a dreamer. There are dreamy touches in your direction which are vastly provocative but have the dynamism that my work needs" (17). Williams may not have realized at first that Kazan was an "artistic tyrant" who demanded and secured "indisputed authority" (85) over set, cast, music, and, eventually, characterization and structure of Williams's plays. Demanding co-ownership of the plays, Kazan fought to "take over the script" (74), sometimes happily encouraging, sometimes strenuously compelling Williams to make substantial revisions. Murphy misses no detail about the triumphs and the tribulations of their collaboration.

Murphy succinctly summarizes Kazan's "signature" that offered Williams "deeply felt characterizations, intensity, careful pacing with frequent climaxes, complex pictorial and kinesic effects, and a great deal of environmental activity" (115). Embedded in Kazan's direction was his adherence to the principles of the Group Theatre, most notably, an unshakable commitment to Stanislavskian models of acting and structure, a belief in "subjective realism" (or encoding "a great deal of the play's meaning in the language of the stage" [96]), a naturalistic view of character, and a strong social consciousness. In many fruitful ways $\mathrm{Ka}$ zan's directorial manifestoes were compatible with 
Williams's beliefs in a "plastic theatre" and recurrent symbolism. When the interplay between the two worked, magic resulted; when strife arose Williams was accused of selling out for commercial success.

Kazan's signature was writ large in Streetcar, the subject of Murphy's longest and best chapter. Reading Streetcar against Kazan's "Notebook," she documents the evolution of the production of Williams's play in the hands of the director-juggernaut. The differences between the reading and the acting versions of Streetcar publicize Kazan's extensive influence. He reinterpreted the music, introduced props, and controlled the New Orleans environment, making more than a hundred changes in Williams's script. Unquestionably the most long-lasting effect of Kazan's influence lay in his interpretation of Blanche as "the emblem of a dying civilization, making its last curlicued and romantic exit" (25).

In her chapter on Camino Real, Murphy asserts that Kazan was responsible for the ultimate reshaping of Williams's play. In a 3500-word letter to Williams after the playwright sent him a draft of Camino, Kazan outlined the process by which he thought the play must be held together; for Kazan the "spine" of Camino must have Kilroy the "clear protagonist," thus restructuring Williams's loose plot into a tight two-act play. Thanks to Kazan's influence, Williams rewrote the script making Kilroy more sympathetic and Marguerite much "softer." Camino marked the turning point in the Williams-Kazan collaboration, for with this play "Kazan had established a precedent of influencing the development of a play's meaning and structure in his work with Williams which was to hold for the rest of their work together" (75).

Turning to Cat, Murphy is on more familiar ground, since most readers know about its different endings, the "Broadway version" inspired by Kazan and Williams's original ending. Murphy again provides extensive evidence about how and why Kazan pushed through three major changes turning Maggie into a more sympathetic character, bringing Big Daddy back for the third act, and having Brick undergo a major "change as a result of his conversation with Big Daddy in Act 2" (99). Although Williams initially agreed to these changes to please Kazan, the playwright was, in the final analysis, angry, feeling that "something in his innermost artistic imagination had been denied or interfered with during the process of collaboration" (128). Beyond doubt, Kazan radically altered Williams's view of character and closure, replacing the playwright's pessimism with "wisdom and acceptance" (129). As a result of their collaboration on Cat, a deep rift separated the two men. But, as Murphy wisely cautions, it was Williams "who made the changes in the script" (129).

Murphy has written a fascinating, meticulously researched and carefully argued study. In some instances, however, she raises questions that she does not answer or does not answer fully. For instance, what was Tennessee Williams's influence on Kazan? Murphy has it more one way than another. She contends that the two men had a "unique spiritual bond" (95), but it is Kazan's, not Williams's, spirit that predominates. I would have liked to see a final chapter that explores Williams's influence(s) on Kazan's directorial style in plays by Williams and other dramatists Kazan worked with. Further, Murphy does not address the ultimate effect of Kazan's powerful influence. More of an apologist for Kazan than for Williams, she avoids the negative side of Kazan's dynamism. Some of Kazan's "enforced" changes weaken Williams's texts, for example cutting the "Della Robbia blue" reference in the last scene of Streetcar to dress Blanche in lavender. Kazan's interpretation of Streetcar as a set of "competing social realities" Stanley's plebeian control versus Blanche's aristocratic vulnerability-has over the years frustrated rather than advanced criticism of the play. And, finally, by making some of Williams's characters more sympathetic, especially Chance Wayne, Kazan had diluted Williams's tragic outlook.

In sum, though, by examining one of the most significant collaborations in American theatre, Murphy sets the groundwork for future studies of such director-playwright teams as Lloyd Richards and August Wilson, Joseph Papp and David Rabe, or Gregory Mosher and David Mamet.

PHILIP C. KOLIN

University of Southern Mississippi

\section{THE PLOT OF THE FUTURE: UTOPIA AND DYSTOPIA IN MODERN DRAMA.} By Dragan Klaić. THEATER: Theory/ Text/Performance Series. Ann Arbor: University of Michigan Press, 1991; pp. viii +258 . $\$ 39.50$ cloth.

Although Goethe associated the narrative forms (the epic and the novel) with the past, and the genre of drama with the present, modern drama seems to modify this classification. Ibsen's analytical dramaturgy put the stress on the past, Chekhov's plays demonstrate both a nostalgia toward a once pleasant past and the hope in a better future. 